\title{
Working Conditions of Journalists in District Swat at the End of Militancy
}

\author{
Yasir Waseem Lqbal ${ }^{1 *}$ and Qazi Farman Ullah²
}

${ }^{1}$ Department of Media Studies, the Islamia University of Bahawalpur, Pakistan

${ }^{2}$ International Islamic University Islamabad, Pakistan

\begin{abstract}
This study aims at investigating the working conditions of journalists in Swat after the militancy ended. Swat is a Militancy hit area and responsibilities of journalists were increased after 2006 when Taliban started their terrorist activities in this scenic valley. It was explored that majority of journalists feel free to write whatever they feel right. Swat journalist were very low paid media workers and have long duty hours than normal eight hours. Majority of journalists feel proud when they introduce their organization. Majority of respondents reported that their organization did not demand seeking of advertisements and did not ask to take care of advertisers' interests. Almost all journalists consider that they have opted this field by choice and want to render services to country and society. It was revealed that media organizations did not compensate their workers in case of loss. Majority of journalists were not satisfied with their salaries and feared that they have threats to be removed from job. They were in search of better opportunities in other media organizations. Majority of respondents consider professional training and workshops necessary for journalists. Respondents feel that journalistic bodies are working for the welfare of journalists; they feel that they have required education of this field and were fit for this profession.
\end{abstract}

\section{Introduction}

Pakistan is considered the most dangerous country in the world for journalists. Pakistani journalists are working in one of the world's most uncertain and hostile environments. Press Emblem Campaign says that In 2011 Pakistan remain very dangerous for journalists. In Pakistan eleven (11) journalists were killed in 2011. More than four dozen have become disabled to such an extent that they cannot even earn their livelihood and more than three hundred and fifty (350) media men were injured while performing their duties. Both military and militants want journalists to cover those stories which favor their objectives. Journalists are attacked when they report news against either side. From last some year's journalists have been working under great pressure, uncertainty, insecurity and hostile environment. The threats to Pakistani journalists are many, especially in the Khyber-Pakhtunkhwa province who are reporting from conflict zone, where military is engaged in operations against insurgency. Journalists face propaganda, threats, coercion, and targeted killings. The safety and security of journalists in conflict zones are very difficult. According to International Federation of journalist report, over sixty three (63) journalists have been killed after $9 / 11$ in Pakistan. Majority of them were killed in Tribal Areas and KP province.

Pakistan Federal Union of Journalists (PFUJ) report, says that journalists are facing so many challenges in Pakistan regarding security, particularly in KP, Tribal areas and in Baluchistan. Media owners provided no protection to journalist's still they continued to work under pressure in the year 2011.

The Geneva based organization Press Emblem Campaign, in its report says that year 2011 was very critical and dangerous for journalists. At least ten (10) journalists were killed and three hundred (300) were wounded, tortured or threatened by Government Agencies. As more as dozen journalists were arrested in false charges while about five hundred (500) media persons were fired by their employers without prior notices. Many have been denied of their salaries.

According to CPJ in his report [1], says the killings of journalists were started in Pakistan in 1992. Those who were killed include Javid Ahmad Nasir of daily Tawer, Faisal Qurashi of London Post, Saleem Shehzad of Asia Times on line, Nasrullah khan Afridi of PTV, Wali Khan
Baber of GEO TV, Misri khan of daily Awsaf, Ghulam Rasul Bagrami of daily Sindh Hidarabad, Jan ullah Hasham Zada of Shamshad TV, Musa Khankhel of GEO TV, Abdur Razaq Johra of Royal TV, Muhammad Ibrahim of express TV, Chishti Mujahid of weekly Akhbar-E-jahan, Zubair Ahmad Mujahid of daily Jang Mir Pur, Hayat ullah Khan Free Lancer, Allah Nur of Khyber TV, Amir Nawab of APTN, Sajid Tanuli of daily Shemal, Fazl Wahab Free Lancer, Shahid Somro of Kawish, Dainal Pearl of Wall Street Journal, Sufi Muhammad Khan of Ummat, Muhammad Samad of Warasi of Parcham Karachi, Muhammad Salah ud din of Takbeer Karachi, Carlos Mavroiem Free Lancer, Nawaz Zulfaqar Memon of Nation, Asad ullah Free Lancer, Muhammad Ismail of PPI, Khadim Hussain Shikh of Khabrian. Those journalists who were killed among them forty eight (48)\% were reporting politics, thirty five (35)\% reporting war, twenty two (22)\% reporting corruption, seventeen (17)\% reporting crimes, nine (9)\% reporting human rights, nine (9)\% reporting culture, and four (4)\% were reporting trade, commerce and business. According to international law attacks on journalists are unlawful. They are considered as civilians, even war propaganda media is not considered military.

Six Newspapers Azadi, Salam, Shamaal, Khabarkar, Nawa-e-Swat and Awaz-e-Shehr were published from Swat. The national dailies also had a significant presence in the area. Cable Television was very popular. In May 2009 when security forces launched operation RahE-Rast in District Swat against terrorists all local Newspapers closed their offices. Newspapers from other parts of the country were also

${ }^{*}$ Corresponding author: Yasir waseem iqbal, Department of Media Studies, Islamia University of Bahawalpur, Pakistan, E-mail: waseem.yasir@gmail.com

Received May 28, 2013; Accepted September 11, 2013; Published September 18, 2013

Citation: Lqbal YW, Ullah QF (2013) Working Conditions of Journalists in District Swat at the End of Militancy. J Mass Communicat Journalism 3: 160. doi:10.4172/2165-7912.1000160

Copyright: $\odot 2013$ Lqbal YW, et al. This is an open-access article distributed under the terms of the Creative Commons Attribution License, which permits unrestricted use, distribution, and reproduction in any medium, provided the original author and source are credited. 
impossible to reach there. After threats from terrorists Cable TV also closed their offices in District swat. Music channels, audio video and CDs shops were also closed after treats. A local Newspaper named Azadi office was blasted by miscreant. Media men were tortured and threatened by terrorists and also by security forces. Both of them want to give coverage to their point of view and cannot tolerate news against them. Terrorist's warend Tele Vision Stations and Newspapers offices on anti-coverage. It was very difficult for journalists to cover the war against terrorists in Swat.

In militancy and operation Rah-E-Rast at least four (4) journalists were killed. Among them a Swat based journalist Moosa Khankhail, working in GEO Tele Vision was killed in February while covering an Aman March of Tahrik-E-Tanzim -E-Nifaz shariat-E-Muhammadi (TNSM). His murder takes place within couple of days when TNSM and Khyber Pukhtonkhwa government signed Nizam-E-Adal Regulatios for peace in District Swat. Qari Shoaib, Abdul Aziz and Siraj-udDin were also killed during this period from February to November 2009. Abdul Aziz of Daily Azadi and Khaberkar was killed in shelling of Military Helicopters in Peuchar village of District Swat because he was in Taliban custody. Siraj ud din of the Daily Nation was killed in a suicide attack on the funeral prayer of a Police officer in Mingora city, District Head Quarter of Swat. Qari Muhmmad Shoaib was killed on 8th November 2008 in Mangora. Almost all media men were migrated from Swat due to threats and dangers to their lives. Pakistan Federal Union of Journalists and other journalistic bodies registered at least two hundred and forty (240) journalists migrated from district Swat, and extended support to them through different ways with the help of other organizations across the country and all over the world.

\section{Review of the Literature}

Arroyave et al. [2] described that in Latin America the study about the journalists professions are relatively new. Diezhadino [3], Garcia [4], Humanes [5] observed that this is also new in Spain to study the journalist's sociological profiles. They issued the first complete study about journalists' habits. Since then, there has been an increasing concentration in such topics. Beltran [6] and Marques de Melo [7] observed that Latin American journalism has been affected especially in Spain since the colonial period. The first part of the audit has focus on some studies in Europe and particularly Spain. It has focued on research on the subject in America. About who were involved in most of the study of the use of journalists is related level of satisfaction reported with the profession. In parts of Europe and North America, it seemed that journalists were happy with their chosen profession [8]. In the Iberian Peninsula, on the other hand, research has explored some remarkable peculiarity. Diezhandino et al. [3] observed that only 47 percent of the journalists interviewed stated themselves to be satisfied from their job. GarcíaTojar [9] stated that reporters marked significant point of dissatisfaction connected to their professions. Rodríguez noted that about 70 percent of Spanish journalists responded to have considered altering their job. In that study, the reasons pointed out were to spend more time with family and peers (36.1 percent); to reduce stress ( 35 percent); to earn more money elsewhere ( 29 percent) and for frustration (25.5 percent). Demers showed that professional satisfaction was higher in decentralized newsrooms, characterized by a higher level of autonomy for journalists. In 1995, Pollard also concluded that the satisfaction depended on factors such as frequent discussions with job supervisors and the journalists' perception of autonomy. Weaver et al. [8] found that the best predictors of job satisfaction were the levels of communication among journalists in the newsroom, especially between reporters and their editors, the perception of autonomy, and the flexibility in their work. Most scholars conclude that professional autonomy, participation, dialog in the news room, and the value of their work were decisive factors in influencing job satisfaction of journalists. Job satisfaction among journalists obviously rests on numerous variables. Job satisfaction involves not only journalists' enjoyment of their jobs, but also to their contribution to their companies. If they were happy with their jobs, they tend to work more effectively. If they were not satisfied, they tend to leave their jobs, or sometimes the field of journalism entirely, because of both personal and organizational consequences of dissatisfaction; the news media need to address the issue. Ramaprasad $[10,11]$ for example, found that journalists in Tanzania and Nepal considered their profession important and joined it because they believed in their goals of informing the public and building society. Research in the tradition of journalist surveys has generally gauged how important the journalistic profession is for its practitioners and may include questions on the reasons for joining the profession. Several press organizations (e.g., Freedom House) rate freedom of the press in countries around the world. Other organizations (e.g., UNDP) include democracy as an indicator of human development [12]. African countries tend to be on the lower end of these ratings. For example, in the Freedom House [13] report on press freedom, in 2004, in 194 countries, Uganda ranked $99^{\text {th }}$, Tanzania ranked $111^{\text {th }}$, Malawi ranked $114^{\text {th }}$, and Kenya ranked $126^{\text {th }}$. Kenya was rated not free, and the other three countries were rated partly free. Analytic pieces on the political, legal and economic frame works of various African countries also provide an assessment of press freedom. These too indicate various constraints on press freedom in most African countries [14]. In Uganda, in addition to laws, economic roadblocks, illiteracy, and an oral tradition, journalists and media continue to battle against the government's entrenched hostility to free expression and criticism. In Malawi, power hungry politicians are increasingly using violence, intimidation, and old and new pieces of legislation against media practitioners to stifle press freedom and gag criticism. Ligomeka [15], in fact, until recently, Malawians had little independent information available to them because the government controlled all sectors of the media [16]. Journalists located in sensible geographic areas in Colombia feel that delinquent groups are constantly threatening their lives and the ones of their loved ones. Insecurity has taken them to keep an anonymous identity in order to protect their lives. In some regions where the public order situation is delicate, journalists decide not to sign their stories or to make an appearance in front of their news cameras. Nevertheless, some bravery acts have to be highlighted in the middle of the limits that the country's armed conflict sets. Journalists use new ways of partnership based on solidarity, in order to complete their job and protect their lives. This takes importance out of the new information, known as "chiva" or breaking news, and leaves it aside, in order to inform to the audience while keeping physical integrity. So, they go to work in groups, and refuse to do reporting in conditions they consider dangerous. Even though the national government has designed a program to protect journalists, reality seems to suggest that criminals still have a lot of advantage, especially in those regions where a void of authority has been detected, and where a great number of communicators are threatened or murdered.

A release for the Fundaciónpara la Libertadde Prensa (Foundation for the freedom of press), gives an account of 2 assassinations in the cities of Cùcuta (Julio Palacios, January 11) and Maganguè (Rafael Prince, February 19), 64 threats, and 103 aggressions against the freedom of speech in 2005. While in a previous study that took place in different Latin American countries [17], issues related to the Personal dimension and the Institutional dimension category emerged in the 
groups discussion with journalists, the Threats and Obstacle dimension was a particular category of the Colombia study, reflecting the particular dynamic of the country. As a journalist stated, "We are between three fires: the paramilitary fire, the guerrilla fire, and the Colombian army fire, you know? One doesn't know the exact time when one may be wounded or murdered by any of these three fires." It is clear that to be a journalist in Colombia is not an easy thing. These four dimensions that emerged from the long discussions in the five cities with the communicators that participated in this study make a manifestation a series of dynamics that belong to the practice of journalism in the country. This research had as an objective to draft the journalist's sociological profile as a subject in the country. The stated in this document reveals fascinating elements, which, at the same time, are reason of worries in the daily life of the professionals that deserve to have a deeper coverage through the use of other techniques that will allow a global and complementary vision of the phenomenon. This way, the profession of journalism in Colombia can count with elements that can help have a better understanding of its development in the country's context.

\section{Theoretical frame work}

For this study, it has been found that structural functionalism approach propounded by Comte, Herbert Spencer, and Durkheim is the most suitable theory to base the research and its finding. Structural functionalism concentrates on the positive and negative functions of social structures. Societal functionalism is a particular type of structural functionalism that aims to explain the role of social structures and institutions in society, the relationship between these structures, and the manner in which these structures constrain the actions of individuals. According to structural functionalists, individuals havelittle to no control over the ways in which particular structures operate. Indeed, structural functionalists understand individuals in terms of social positions. For example, when the structural functionalists Kingsley Davis and Wilbur Moore discuss social stratification, they do not refer to individuals, but to the positions these individuals occupy. It is not individuals who are ranked, but positions that are ranked according to the degree to which they contribute to the survival of society. High-ranking positions offer high rewards that make them worth an individual's time and effort to occupy. The structural functionalist account of stratification has been criticized on the grounds that there must be other ways to motivate individuals to occupy particular positions and perform certain tasks without such a disparate system of rewards. This theory applies to current phenomena because journalists work according to the structure of organization as well as social structure. In the light of above theory research found those journalists are not freely working because, there media organization opposed certain restriction on them. From selection of stories to their dissemination and even media organization demand their workers to get advertisement from business enterprises they are also asked to don't hurt the interest of advertiser, so we found journalist work within organizational structure and sometime attained satisfaction about their position and sometime feel bound to follow organizational instructions. Apart from organizational structural journalist also face social structure of their respective society. Sometime there professional ethic allowed him to report on certain issue but he is bound in his social affiliation. Contrary to both structure journalists helpless to report specific issue because, sometime he tie with self-structure.

\section{Research questions}

- What are the working conditions of journalism in District Swat?

- What is the Socio economic status of Swat Journalists?

- Dose there exist media organizations in Swat?
- What are the facilities provided by media organization to journalists?

- Is there any training of journalists provided by media organizations?

- What are the restrictions on freedom of expression?

- Dose journalistic bodies work for the welfare of journalists?

- Dose journalists are fit for this profession?

- Dose journalists feel their job secure?

- Are their salaries according to wag board award?

\section{Methodology}

This research has been conducted by having quantitative analysis. Survey questionnaire was developed to investigate about the working conditions of journalists of district Swat. The researcher kept in account the importance and impact of phenomenon journalism field and selected that portion of society which can better understand the importance of this research work. Therefore, all members of Mingora press club were selected. Census sampling technique was used for the all members of Mingora press club, because the process of examination of every member of such a population is called a census. In this research the researcher used survey technique because it is the most appropriate tool to inquire instant phenomena, and Likert scale was used to fill the questionnaires from the respondents. This research was limited to Mingora press club members only.

\section{Rationale for sectional of Mingora press club}

Swat is scenic valley of Pakistan, people from all over the world come see the beauty of valley, but after 2006, Taliban evaporate the peace of Swat. After 2007, National and international media focus Swat Taliban activities, during military operation (May 2009) in Swat journalists faced great difficulties and four journalists loosed their lives while reporting in that area. Mingora is the hub of business, education and journalism not only in district but in whole Malakand division. Therefore researcher selected Mingora press club members.

\section{Analysis of the data}

In this research the collected data were interpreted by using SPSS and were expressed in simple percentage and cross tab. Findings and conclusion were drawn from the analyzed data through cross tabulation, and data was presented in tables and charts.

\section{Operational definition of variables}

Autonomy: Independence or freedom, as of the will or one's actions: the autonomy of the individual. The purpose of this variable was to measure the independent or freedom of journalist in operation, allocative and admintrative, role in organization.

Organizational performance \& association: According to Richard Organizational performance encompasses three specific areas of firm outcomes: (a) financial performance (profits, return on assets, return on investment, etc.); (b) product market performance (sales, market share, etc.); and (c) shareholder return (total shareholder return, economic value added, etc.)". In present study this variable is used to measure the association of journalist with their organization, regarding rating of organizational performance, impact on the community, policy emphasis in news quality and policy emphasis in advertising profits and supervisor comments.

Professional variables: A professional is a person who is paid to undertake a specialized set of tasks and to complete them for a fee, 
and in this study it explored as Lack of professionalism, Education and training in their relevant field, Relationship with the journalists bodies and Satisfaction with their professional abilities.

\section{Analysis and interpretation of data}

For this research researcher collected data from members of Mingora press club. All respondents were male because there were no female members of Mingora press club. According to the collected data $38 \%$ respondents are in age group of $20-30$ years, $44 \%$ have age group $31-40$ years, and $16 \%$ were in age group of $41-50$ while $2 \%$ respondents were in age group of 51-60 years. Majority of respondents have very low income, it was revealed that $86 \%$ earn 10000-20000 Pakistani rupees per month, $6 \%$ earn $21000-30000$ rupees, $2 \%$ earn $31000-40000$ and 51000-60000 rupees and 4\% earn more than 61000 rupees. Majority of the respondents, $80 \%$ were married while $20 \%$ were single. $18 \%$ respondents were metric, $26 \%$ were F.A, F.Sc, and $28 \%$ were BA and MA respectively. Majority of the respondents $44 \%$ have their M.A degree in Journalism and Mass communication, $40 \%$ have M.A humanities degrees while $16 \%$ have other degrees. Majority of the respondents $64 \%$ were working in newspapers, $10 \%$ in radio, and $18 \%$ in TV while $8 \%$ were working in news agencies. Majority of the respondents $86 \%$ worked as reporters, $4 \%$ as photographers, and $2 \%$ were freelancer.

Job autonomy, roll in determination of strategy and freedom of expression: It has been found that a clear majority (about 52\%) report or work without any fear or favor or feeling themselves under any internal or external pressures. However, interestingly, a considerable number of respondents (38\%) did not respond to whether they work under certain restrictions of any nature (Figure 1). It has been quite interesting to explore the relationship between age and feelings of work under restrictions. It has been revealed that as people growing in age their perceptions about working under pressure tends to increase. Nonetheless, young respondents have been found that feeling themselves free in their work without having any or little restrictions. Although a considerable number of them did not respond, this means that they were indecisive in this regard. This was also a sort of pressure
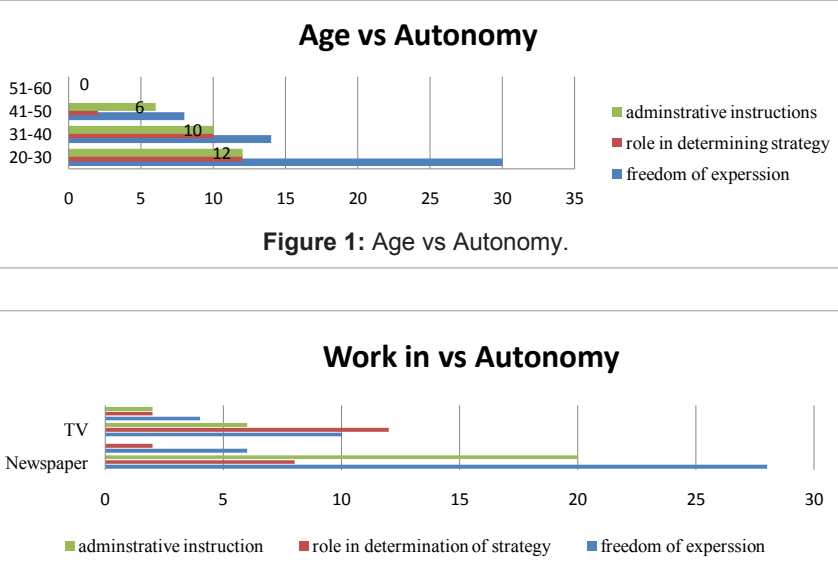

Figure 2: Work vs Autonomy.

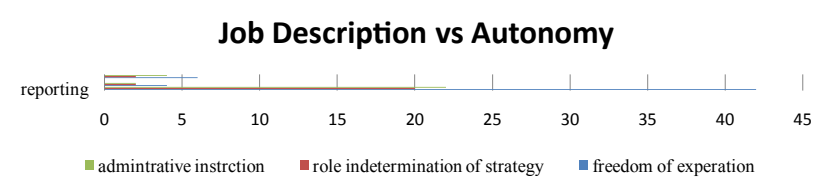

Figure 3: Job Description vs Autonomy.

\section{Incom vs job Autonomy}

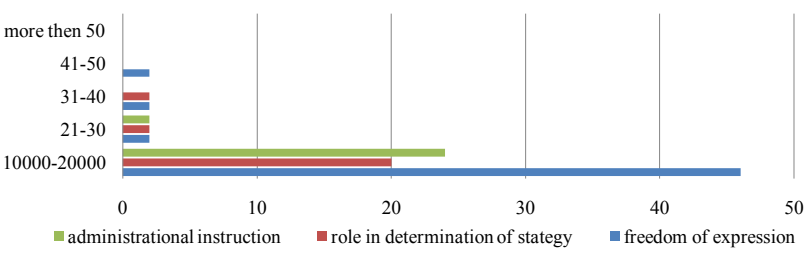

Figure 4: Income vs Job Autonomy.

which they while responding to the statement. While it was found that young respondents do not feel such restrictions and pressures. Likewise as their experience increases they feel themselves in chains. Considerable number of young respondents (about 40\%) did not think that they have any role in determining the strategic goals of their organizations. From the analysis it was revealed that less experience respondents did not favor but as experience increases the respondents favor that they play role in determining the strategic goals of their organization. The relationship of education with the role explore that high qualified respondents think that their role in important in this regard. Majority of young respondents do what they think right and do not bound themselves to administrative instructions. But on the other hand relationship of experience shows that less experience respondents follow the instructions of administration while planning coverage of an event as compared to more experienced respondents (Figure 2). Attachment with the kind of media has also been found to be of relevance and it has been found that respondents from print media feel relatively more free in their choices towards their assignments as compared to electronic media. A considerable number of respondents (about 30\%) did not show any response. The relationship of electronic and print media respondents shows that respondents working in print media think that their role is worth important as compared to electronic media respondents. It means that the print media workers consider their role more important than electronic media workers in determining the strategic goals of the organization (Figure 3). On the other hand (42\%) respondents working as reporters in media organizations also did not feel themselves under pressure although they were to meet the dead line and cover all the events of their beats daily. Interestingly (about 36\%) respondents did not give any response working as reporters. It has been worth mentioning that high qualified respondents having Master degrees were feeling themselves more under pressure as compared to low qualified respondents. Although a considerable number of them did not respond, this means that they feel themselves under pressure while responding to the statement. While it was found that young respondents do not feel such restrictions and pressures. Half of the respondents (about 50\%) did not think that they play any role in determining the strategic goals of their organization. It shows that organizations do not took them in confidence in important decisions. Only $24 \%$ argue that they play a decisive role in this regard. Interestingly majority of the respondents (48\%) workings as reporters were of the opinion that they do not play any important role in this regard (Figure 4 ).

The relationship of the income and the role in determining the strategy of the organization revealed that low paid respondents (about $44 \%)$ think that there is no role of them in determining the strategic goals of their organization. Majority of low paid respondents were of the opinion that they were free to discuss or write whatever they feel right and did not feel themselves under any pressure. A considerable number of respondents (about 30\%) did not show any response. 
Citation: Lqbal YW, Ullah QF (2013) Working Conditions of Journalists in District Swat at the End of Militancy. J Mass Communicat Journalism 3: 160. doi:10.4172/2165-7912.1000160

A clear majority of respondents (56\%) feel themselves free in covering of an event and do not need to follow any administrative instruction in this regard. Majority (48\%) of low paid respondents do not follow administrative instructions. It is quite interesting that none of the high paid respondents was agree, which means that they follow the instructions. To explore the relationship of education and the feeling of work under administrative instructions, it has been revealed that as the qualification increases the respondents follow more the instruction of administration (Figure 5).

The analysis shows that the respondents working in print media do not follow administrative instructions while respondents of electronic media follow. The analysis shows that print media workers feel themselves more free as compared to electronic media workers.

Organizational performance, interest of advertisers, policy about advertisements and organizational instructions: It has been found from the analysis that almost all the respondents (98\%) value their organization very high and feel proud that they were working with that organization. It is quite interesting that $(84 \%)$ low paid respondents feel proud on their organizations (Figure 6). About (92\%) respondents think that people rate high their organizations. An overwhelming majority of young and low paid respondents were of the opinion that people like their organization. It means that they were satisfied with the reputation of their organizations. According to analysis it was found that majority of respondents (82\%) were asked to follow the organizational instruction while making a news story. The relationship of age, experience and income to the organizational instruction shows that clear majorities of young respondents $(68 \%)$ low paid $(76 \%)$ and less experience were asked to follow organizational instruction. From the analysis it was revealed that there was no significant difference in the responses of low and high qualified respondents. It is also quite interesting that low paid (52\%) respondents feel themselves free while constructing news story and they were not asked by the organization to take care of the advertisers. From this it is clear that majority of journalists were not facing any compulsion and they were free to express what reality was. The relationship of income shows that majority of low paid (48\%) have no organizational orders in this regard It is worth mentioning that young respondents about (40\%) were never experienced such situation. Likewise low paid respondents also opinioned same. From the analysis it is clear that the media workers have freedom of (Figure 7) expression and administration do not hinder in their way. It is quite interesting. It was revealed that print media respondents were more free in this regard

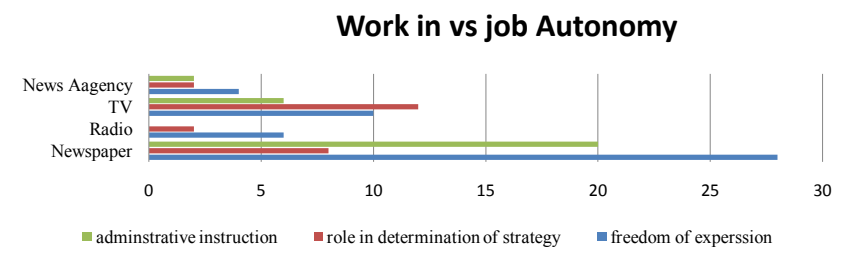

Figure 5: Work vs Job Autonomy.

\section{Age and Income vs Organizational Association}

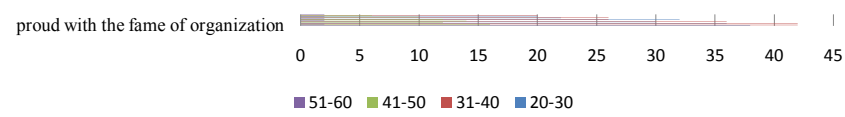

Figure 6: Age and Income vs Organizational Association.

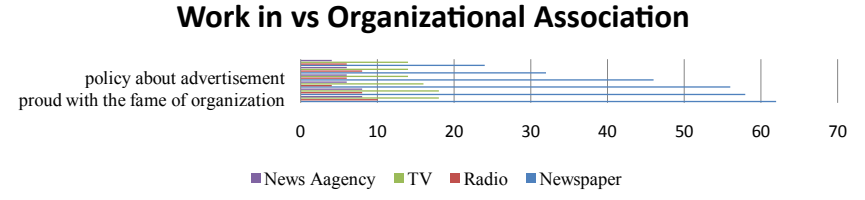

Figure 7: Work vs Organizational Association.

\section{Job Description vs Organization Association}

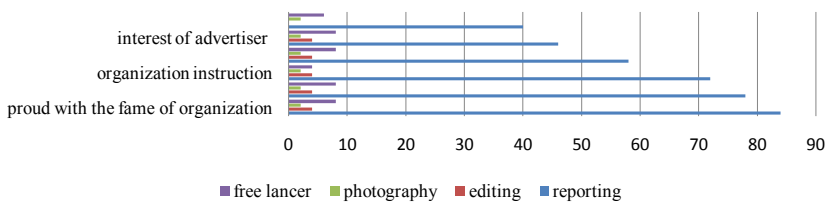

Figure 8: Job Description vs Organization Association.

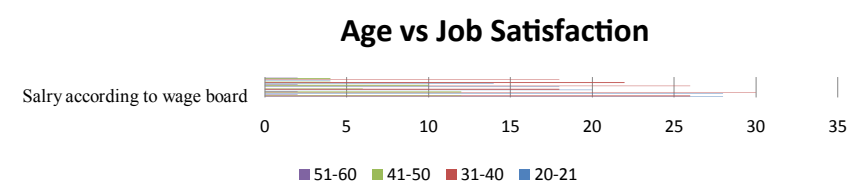

Figure 9: Age vs Satisfaction.

as compared to electronic media. It has been found that a clear majority $(60 \%)$ construct news story objectively and do not care of the interest of advertisers, and the organization also does not compel them for doing so. About (34\%) work under such type of administrative instructions. It means that the objectivity of the news stories was affected by economic and commercial factors. The print media respondents were more free as compared to electronic media workers who feel themselves more bound. From the analysis it was revealed that respondents having 4 and more than 4 dependents expressed that they were not asked to take care of the advertiser's interests (Figure 8).

Advertisements are like blood for any media organization in this commercial and competition era but it is quite interesting that (72\%) respondents were does not compel by their organizations to look for advertisements and they only concentrate on their beat. Although (14\%) did not gave their response while (14\%) were demanded by organizations to look for advertisements along with their beat coverage. Likewise it is worth mentioning that reporters think themselves more free as compared to other workers of the media organizations regarding the advertisements seeking. From the analysis it was revealed that low paid respondents (64\%) opinioned that there is no compulsion on them for looking advertisements from organizational administration. But on the other hand (32\%) reporters were asked to follow organizational instructions. Majority of respondents (48\%) reported that their supervisor do not comment on their news story. It means that they are free to discus or write whatever they feel right and they have no administrative censer or guide lines. But on the other hand 32\% were of the opinion that their supervisor comment on the story, and about $20 \%$ did not respond which means they were reluctant to comment on it.

Salary, job security, promotion, work load, and organizational compensation in case of loss: It was found that as the age increases the respondents dissatisfaction also increases. The same situation is with the relationship of experience and the wages of the respondents. 
Analysis revealed that as the experience of the media workers increases resultantly the dissatisfaction over the wages also increases (Figure 9). As age and dependents increases the fear about job security increases. From the analysis it was found that those respondents having more than 40 years age and having 4 and more than 4 dependents expressed their fear about job surety. It is interesting to mention that after analysis it was found that the less experience respondents expressed their dissatisfaction in this regard. Analysis shows that as the age grow and their dependents increases the dissatisfaction increases about the wages. Likewise the relationship of the education revealed that more qualified respondents were dissatisfied from their wages as camper to low qualified. As the media workers were constantly exposed to physical threats while performing their duties in the field. It was found that a very clear majority (about 56\%) think that their organizations do not compensate them in case of any damage of life and property during performing the duty. About $26 \%$ did not respond which also rises question in this regard (Figure 10).

Regarding their income and wages majority respondents expressed dissatisfaction. A very clear majority $(60 \%)$ of low paid respondents expressed their dissatisfaction over their salaries. It is very interesting that $34 \%$ low paid respondents shows satisfaction on their duty hours as compared to high paid respondents. But on the other hand $28 \%$ of low paid were dissatisfied from their duty hours. About $38 \%$ of the low paid respondents do not feel any threat about being removed from the job, it means that they always search for better wages and if an opportunity comes he may took change. Majority (48\%) of the low paid respondents reported that they were not compensated in any loss. It is quite interesting that $50 \%$ low wages workers of the media houses agree that they have the opportunity of promotion depending on their performance. Regarding the fear from firing the job the analysis shows that $44 \%$ respondents do not feeling any threat about being removed from the job but the $32 \%$ respondents reported that they fear that any time they can be removed from the job. The $22 \%$ respondents do not give their responses; it means that they are uncertain about their job security (Figure 11).

From the analysis it was revealed that as compared to electronic media print media workers were dissatisfied more. It shows that in print media the wages of the workers were not according to the wage board award but the electronic media workers receive better wages then print media. It is quite interesting that the electronic media workers feel threatened about firing from the job as compared to print media workers. It was also revealed that respondents working in print media were not satisfied from their wages as compared to electronic media.

\section{Income vs Job Satisfaction}

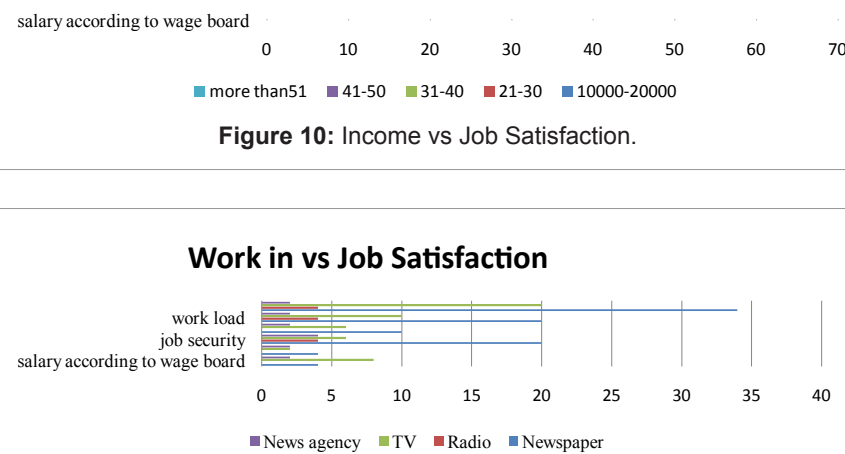

Figure 11: Work in vs Job Satisfaction.

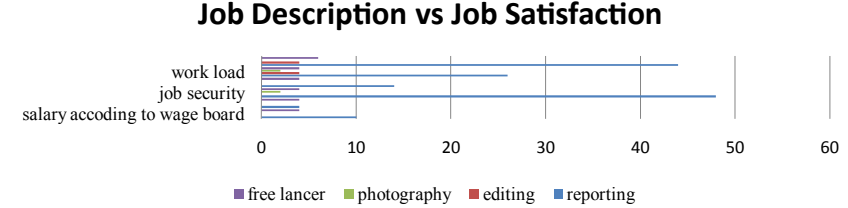

Figure 12: Job Description vs Satisfaction.

Comparatively the electronic media houses pay more to their worker as compared to print media organizations. It is worth mentioning that more electronic media respondent's shows satisfaction over compensation in case of any loss as compared to print media workers. It means that electronic media houses take care of their workers. It shows that electronic media houses are more workers friendly as compared to print media organizations. As compared to electronic media the print media workers were less satisfied from their duty hours. About $38 \%$ reporters were not satisfied from their duty hours while about $22 \%$ did not shows any response which means uncertainty in this regard. It is worth mentioning that print media workers responded positively about the promotion in their organizations on their performances as compared to electronic media workers (Figure 12).

As compared to other media workers $40 \%$ reporter expressed their fear of being removed from the job. But interestingly the $28 \%$ reporters feel no threat about their removal. Majority of the reporters (66\%) were not satisfied from their wages as compare to other media workers, because the reporters travel place to place to cover their beats and assignments. They suffer more as compare to others workers. From the analysis it was also revealed that as the dependents increases the respondents expressed dissatisfaction over their salaries, because their expenditures increase. The reporters are the back bone of any media organization, face great hardships in reporting and expose to more dangers. After analysis it was found that majority of the reporters (50\%) were not satisfied from the organization in regard of compensation in case of any loss or damage to life or property. About (22\%) did not showed any response which is also worth mentioning that why they were reluctant to show their response freely. About the duty hours $40 \%$ expressed their dissatisfaction. But interestingly $22 \%$ did not respond about this, while $36 \%$ were of the opinion that they do not have tough duty hours as compared to other professions. Although there is no significant difference in the responses of favor or against to this statement but the $22 \%$ respondents cannot be ignored, who did not commented. We can conclude that majority of the respondents are not satisfied from their duty hours. They think that they work more as compared to other professions who have fix duty hours but in the field of journalism the duty hours are not fix. They were on call duty and can be called any time because of the changing political, law and order situation. The relationship of education shows that high qualified respondents were not satisfied as compared to low qualified respondents. A clear majority (54\%) of the respondents were satisfied that they have the opportunity to get promotion in their organization depending on their performance and efficiency. While $28 \%$ showed dissatisfaction in this regard and $18 \%$ remains neutral and did not showed their responses which means that they are uncertain in this regard or have some reservations. It was revealed from the analysis that as the qualification of the respondents increases their chances of getting promotion increases. Likewise reporters were more agree as compare to other media workers because they do more than others.

Professionalism, education, trainings, relationship and role of journalistic bodies: Objectivity is most important feature of a news 
story. It is against the ethics of journalism to include personal feelings in a news story (Figure 13). The news story must be objective in all regards. If someone include personal feelings in his writing then that writing is consider literature not news. From analysis it was revealed that $46 \%$ feel that they do not like it to alter the story. $16 \%$ remains neutral and $38 \%$ feel that there is no harm to alter the story to make it interesting. A very clear majority $92 \%$ believe that they think that they need to be more honest and unbiased in reporting/writing/ my work. It is interesting that young journalist were agree more than aged. Likewise low paid were more agree. The relationship of education shows that as qualification improves the respondents think that they must to be honest. It is quite interesting that as compare to mass communication degree holders the humanities degree holders were more. The print media respondents were more as compare to electronic media workers. $80 \%$ reporters were of the opinion that they must be more honest (Figure 14).

The journalists working as correspondents think that they need more honesty then the contract employs. It is very interesting that as dependents raises the respondents reported that they need more honesty. 58\% respondents having 4 and more than 4 dependents were agree. Respondents giving 1-2 and 3-4 were more than giving more than 4 hours to family. Less experience respondents think that they need more honesty as compare to more experience respondents. $42 \%$ journalists did not respond to this statement because that most of the journalists do not care about professional honesty and objectivity. $46 \%$ were agree and only $12 \%$ were disagree. It is quite interesting that most of the respondents with improving of educational qualification agree that the journalists are not honest. But it is also worth mentioning that $26 \% \mathrm{MA}$ and BA qualified were remains neutral. 22\% respondents having mass communication degrees and 20\% having humanities degrees were remain neutral which cannot be ignored. The majority of print media respondents were neutral as compare to electronic media workers. But the same number of respondents of both media houses were agree that the journalists do not take care of professional honesty and objectivity. $36 \%$ reporters were agree that the journalists were not honest but $38 \%$ were neutral to respond.

Majority (82\%) of the journalists think them fit for the journalism profession. It was found that as experience increases the respondents think that they have chosen right profession. The relationship of education and the choice of the profession explored that more qualified were of the opinion that they are fit for the job as compared to low qualified respondents. There is no significant difference in the responses

\section{Job Description vs Professional Ablities}

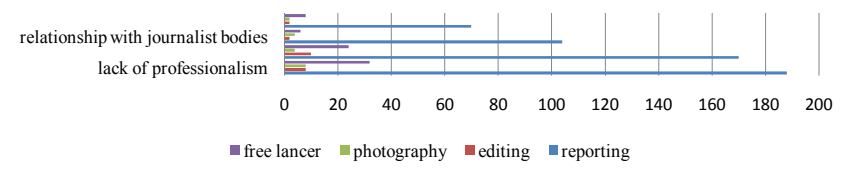

Figure 13: Job Description vs Professional Ablities.

Work in vs Professional Ablities

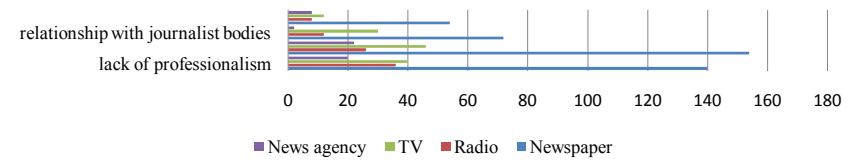

Figure 14: Work in vs Professional Ablities.

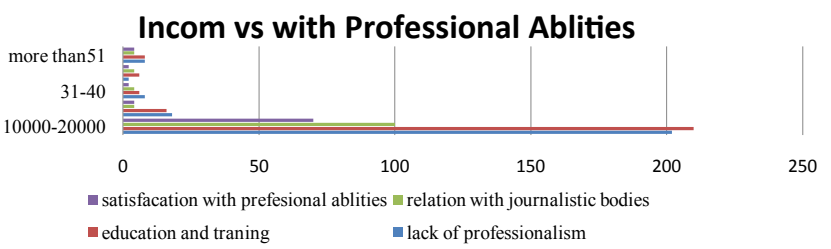

Figure 15: Income vs with Professional Abliries.

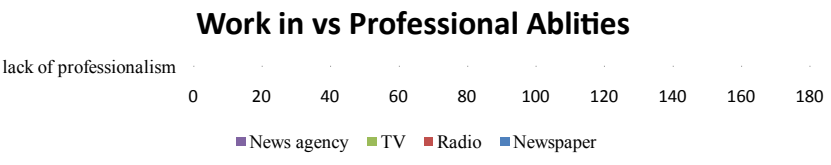

Figure 16: Work in vs Professional Ablities.

with the relationship of experience. It is quite interesting that as the dependents increases the responses were positive in this regard. 52\% respondents were agree who have 4 or more than 4 dependents. The relationship of time for family and the choice of profession revealed that $46 \%$ respondents who gave 3-4 hours to family think them fit for the job. $70 \%$ reporters agree with this (Figure 15).

The relationship of income shows that $42 \%$ low paid think it not good to alter the story. But $32 \%$ were agree that there is no harm in it. The relationship of education explore that as qualification improves the respondents do not think it good to alter the story to make it interesting for the readers. But the low qualified were agree more. It was revealed that the mass communication degree holders think it harm because they know the ethics of journalism that objectivity is must. Majority of print media workers think it is harm to alter the story. The majority of reporters $44 \%$ think it harm. $26 \%$ did not think so and $16 \%$ remains neutral in this regard. It was revealed that respondents having more dependents think that it is no harm because they are busy in family life more. More interestingly less experience think it harm as compare to high experience respondents (Figure 16).

A very clear majority of journalists believe that there is no harm in borrowing the story of your beat from other organization journalists. But $26 \%$ disagree with it while $14 \%$ remains neutral and did not respond in this regard. It was come to know that majority of young journalists do not think it any harm. 48\% low paid respondents agree that this is not a bad thing but on the other hand $24 \%$ disagree and $14 \%$ remains neutral. It is quite interesting that high qualified think it not bad as compare to low qualified respondents. It was explored that the percentage of the mass communication degree holder's respondents were greater than other degrees holder in this regard. As compare to electronic media the print media workers feel it no harm. Interestingly more journalists $46 \%$ were agree but on the other hand $26 \%$ disagree with it. The relationship of the number of dependents shows that as the dependents increases the respondents expressed it no harm because they have so many engagements as compare to single or less dependents respondents. It is also worth mentioning that as the respondents giving more time to family their responses shows that they do not think it harmful to borrow a news story from other journalists. As the experience increases it was revealed from the analysis that they think it is not good to borrow. The print media workers were more than electronic media workers in thinking them fit for the job

Majority of respondents about $62 \%$ think that they have the required education to become a journalist. But $30 \%$ disagree with this. It 


\section{Job Description vs Professional Ablities}

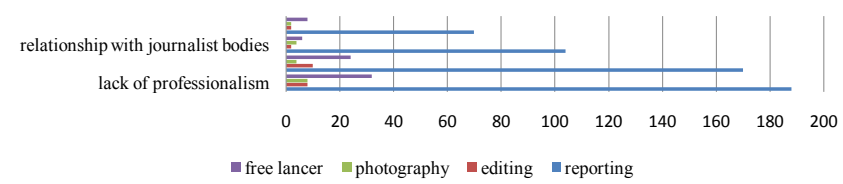

Figure 17: Job Description vs Professional Ablities.

is quite interesting that $10 \%$ of the total respondents having journalism degree expressed that they have not the required education for the field. It is also worth mentioning that about $54 \%$ low paid think that they have the required education but interestingly $28 \%$ were disagree with this. The more educated were agree as compared to low qualified. $34 \%$ newspaper respondents were agree but on the other hand $24 \%$ were disagree. More Respondents working in electronic media think that they have the required education and only $2 \%$ were disagree. It is quite interesting that $50 \%$ of reporters think that they have the required education but $28 \%$ think it is not so.

Over whelming majority (92\%) respondents feel that they need professional training in their specific beat. The respondents having mass communication degree think that they need more training in their beat. From the analysis it was revealed that the more educated respondent's need more training as compare to low educated. It was come to know that young journalists respond that they need more training as compare to aged. It means that young journalist want to know more and more about their specific beat. $78 \%$ low paid respondents were agree that more professional training is needed for him in his beat. As the single respondents were more so here also the single were agree (Figure 17).

From the analysis it was come to know that over whelming majority (94\%) believe that there is need to conduct training workshops for the journalists more often. It was revealed that less experienced respondents were more of the opinion that the need is greater as compare to more expert respondents. Majority of reporters $82 \%$ says that the training is must as compare to other media workers. The ratio of the print media respondents $62 \%$ was more as compare to electronic media. It is quite interesting that with the improvement of academic qualification the respondents need the workshops and training more. It is quite interesting that the respondents having MA degree in journalism and mass communication $42 \%$ were respond that they need that there is need of the workshops for the journalists. It means that they know the importance of training workshops for the journalists more often as compare to other respondents who have other degrees then the relevant field.

A clear majority $68 \%$ respondent believe that journalistic bodies were working for the cause of journalism and $58 \%$ admit the role of those bodies for the welfare of journalists. But about 23\% did not respond in this regard. On the other hand $19 \%$ did not believe the role of those bodies. Interestingly there is no significant difference with the relationship of experience and the role of those bodied for the promotion of journalism and the welfare of journalists.

\section{Conclusion}

According to analysis all members of Mongora press club were male and there is no female press club member in district Swat. Majority of respondents (44\%) were in age group of 31-40 years. Majority of respondents were low paid and earn only 10000 to 20000 Pakistani rupees per month. In total respondents $80 \%$ were married and about $60 \%$ have 4 or more than 4 dependents. It was revealed that $44 \%$ journalists have MA Journalism and Mass Communication degrees. The majority of respondents (64\%) working in newspapers. Majority $86 \%$ respondents were working as reporters in different media organizations. Only $14 \%$ respondents have permanent jobs and $32 \%$ were on contract basis. Majority of respondents $78 \%$ have their self-owned houses. About 50\% respondents gave 3-4 hours daily to their families. Majority of respondents have less than 5 years' experience in practical journalism. A over whelming majority $98 \%$ have no pensionable jobs. From the analysis of collected data it has been found that a clear majority (about 52\%) report or work without any fear or favor or feeling themselves under any internal or external pressures. About (42\%) respondents working as reporters in media organizations also did not feel themselves under pressure. Majority of young respondents reported that they do what they think right and do not bound themselves to administrative instructions. Half of the respondents (about 50\%) among which $40 \%$ were young having age group 30-40 did not think that they play any role in determining the strategic goals of their organization. Another survey of 1123 journalists in Germany conducted in 1992 by Weischenberg indicated that most of the journalists perceived their role as analyzers or disseminators of information. It was explored that (56\%) feel themselves free in covering of an event and do not need to follow any administrative instruction in this connection. It has been found from the analysis that almost all the respondents (98\%) value their organization very high and feel proud that they were working with that organization. This strengthen the study of Herzberg conducted by 1966, he observed that professional satisfaction increases when organization value and recognize the work of their workers and gave them opportunity to make something different. About (92\%) respondents think that people rate high their organizations. The relationship of age, experience and income to the organizational instruction shows that clear majorities of young respondents (68\%) low paid (76\%) and less experience were asked to follow organizational instruction. It has been found that a clear majority (60\%) construct news story objectively and do not care of the interest of advertisers, and the organization also does not compel them for doing so. It was come to know after analysis that $(72 \%)$ respondents were does not compel by their organizations to look for advertisements and they only concentrate on their beat. Majority of respondents (48\%) reported that their supervisor do not comment on their news story. Very clear majority (60\%) of respondents expressed their dissatisfaction over their salaries. It was also found that very clear majority (about 56\%) think that their organizations do not compensate them in case of any damage of life and property while performing their duty. About $40 \%$ reporter expressed their fear of being removed from the job. It was found that majority $(60 \%)$ respondents were happy in their work environment, but $40 \%$ respondents expressed their dissatisfaction over duty hours. A similar study was conducted in Spain, by Rodríguez Andrés (2000) noted that about seventy percent media men opinioned that they have long duty hours as compared to other professions, where eight hours is normal duty. Another study about journalists duty hours was conducted in Colombia, by Cardona in 2004 also reported about long and exceeded duty hours of journalist in the country.

It is also worth mentioning that majority (86\%) of reporters do not fell any stress in their work environment.

A clear majority (54\%) of the respondents were satisfied that they have the opportunity to get promotion in their organization depending on their performance and efficiency.

An over whelming majority (92\%) of respondents felt proud of being journalist. This finding strengthen the study of Weaver et al. 
Citation: Lqbal YW, Ullah QF (2013) Working Conditions of Journalists in District Swat at the End of Militancy. J Mass Communicat Journalism 3: 160. doi: $10.4172 / 2165-7912.1000160$

[8] conducted in Germany, the study shows that 95 percent of the journalists reported that they were pleased with their jobs. In Canada, 85 percent claim their satisfaction, as did 87 percent in France, 82 percent in the United Kingdom, and 77 percent in the United States.

A very clear majority about $82 \%$ of young respondents age range between 20 to 30 and 31 to 40 years respond that they their work is worthwhile for their organization. About (60\%) of respondents were agree that they always look for the better opportunities in other media organization. The analysis shows that $52 \%$ low paid respondents were seeking for change for better wages. Majority $(82 \%)$ of the journalists think them fit for the journalism profession. Almost all the respondents $98 \%$ were of the opinion that they were contributing towards the development of the country and nation. This study is similar to the study conducted on Tanzania and Nepal journalists in 2002-2005 by Ramaprasad, the researcher noted that the respondents opted this profession because they consider this profession as a means of informing people and to render services to society, their country and nation. Majority of respondents about $62 \%$ think that they have the required education to become a journalist. Over whelming majority (92\%) respondents feel that they need professional training in their specific beat. From the analysis it was come to know that over whelming majority (94\%) believe that there is need to conduct training workshops for the journalists more often. Majority of reporters $82 \%$ respond that that professional training for reporters is must. A clear majority $68 \%$ respondent believe that journalistic bodies were working for the cause of journalism and $58 \%$ admit the role of those bodies for the welfare of journalists.

\section{Recommendations}

After conducting this very study and exploring the working condition of journalist in Swat the researcher can safely say that these flowing areas can be purposed for further studies. New statistical packages and new data may be considered in further researches keeping in view the new techniques and equipment which have been adopted by the news industry after the advent of new media. With the minor changes the questionnaire can be easily adapted for investigating the working condition of any war affected area around the globe. Though the current study has uncovered almost all the obstacles and influences which were affecting professional obligations of journalist working in swat yet a further study implementing comparative analysis of the working condition pre and post war in swat can be very insightful in this regard.

\section{References}

1. www.cpj.org/about/CPJ.2011.Annual.Report.pdf'

2. Arroyave JA, Barrios M (2009) What It Takes to Face the Challenges: Sociological Profile of Colombian Journalists" Paper presented at the annual meeting of the International Communication Association, Marriott, Chicago.

3. Diezhandino M, Bezunartea O, Coca C (1994) La élite de los periodistas [The elite of journalists]. Bilbao: Universidad del País Vasco.

4. García de Cortázar M, García de León MA (2000) Profesionales de Periodismo: Hombresy mujeres en los medios de comunicación [Professionals in journalism: Men and women in the media]. Madrid: CIS.

5. Humanes ML, Ortega F (2000) Journalists century. Journal of Information and Communication 4.
6. Beltran LR (1975) Form of cultural dependency: Research ideologies in conflict Journal of Communication 25: 8-15

7. Marques de Melo J (1988) Communication theory and research in Latin America: A preliminary balance of the past twenty-five years. Media, Culture and Society 10: 405-418.

8. Weaver D, Wilhoit C (1996) The American journalist. CITY, NJ: Lawrence Erlbaum.

9. García Tójar L (1999) El factor humano. Socioanálisis de los productores de la información periodística en España [The human factor: Psychoanalysis of the producers of news in Spain]. Doctoral thesis. Madrid: Universidad Complutense de Madrid.

10. Ramaprasad J (2002) Tanzanian journalist profile: Demographics, work background, choice of profession, and assessment of press freedom. International Communication Bulletin 37: 2-17.

11. Ramaprasad J (2005) Nepalese journalists: Idealists, optimists, and realists The Harvard International Journal of Press/Politics 10: 90-108.

12. Stevenson RL (2004) Press Freedom and National Development in Africa after the Cold War.

13. Freedom House (2005) Freedom of the press.

14. Tettey WJ (2001) The media and democratization in Africa: contributions constraints and concerns of the private press. Media, Culture \& Society 23 5-31.

15. Ligomeka B (2002) Malawi losing shine on media. News from Africa.

16. Oguz O (2004) Malawi: IPI 2004 world press freedom review.

17. Arroyave J, Hughes S (2004) Market-Driven Journalism and Tabloidization of Mainstream Mexican TV News. Paper presented to the XXV International Congress of the Latin American Studies Association, Las Vegas, NV. 